\title{
AKURASI
}

\section{DETERMINAN MANIPULASI AKUNTANSI DI LAPORAN KEUANGAN DENGAN RASIO INVESTASI BERBASIS AKRUAL}

\author{
Serly ${ }^{1}$, Andy Lau ${ }^{2}$ \\ Universitas International Batam ${ }^{12}$
}

15erly@uib.ac.id, ${ }^{2}$ 1842179.andy@uib.edu

\begin{tabular}{ll}
\hline INFORMASI ARTIKEL & ABSTRAK \\
\hline Article history: & Penelitian ini bertujuan untuk menguji pengaruh rasio investasi berbasis \\
Dikirim tangal: $15 / 08 / 2021$ & akrual dalam penentuan manipulasi akuntansi pada perusahaan publik \\
Revisi pertama tangal: $18 / 09 / 2021$ & terdaftar di Bursa Efek Indonesia periode 2015-2019. Penentuan \\
Diterima tanggal: $18 / 10 / 2021$ & manipulasi akuntansi dianalisis dari rasio investasi berbasis akrual \\
Tersedia online tanggal $27 / 12 / 2021$ & seperti laba per saham, dividen per saham, price earnings ratio, dividend \\
& ratio, total share profitability, dan dividend profitability. Hasil penelitian \\
& menunjukkan hanya price earnings ratio dan total share profitability yang \\
& signifikan memengaruhi penentuan manipulasi akuntansi, yang \\
& mengindikasikan bahwa manajemen perusahaan yang ingin mencapai \\
& target laba yang sudah ditentukan cenderung melakukan manajemen \\
& laba. Hasil penelitian ini mengimplikasikan bahwa manajemen memiliki \\
& motif untuk melakukan manipulasi terhadap laporan keuangan untuk bisa \\
& menunjukkan nilai price earnings ratio dan total share profitability yang \\
& paling bagus untuk meningkatkan kepercayaan investor sehingga \\
& berdampak pada peningkatan harga saham perusahaan.
\end{tabular}

Kata Kunci: manipulasi akuntansi, rasio investasi, laporan keuangan

\begin{abstract}
This study examines the effect of the investment ratio measured on an accrual basis for determining the accounting manipulation of the listed firm in the Indonesian Stock Exchange. This study was done on publicly listed firms in Indonesia, with sample data ranging from 2015 to 2019. Determinants of accounting manipulation could be analyzed from investment ratio accrual-based such as earnings per share, dividend per share, price-earnings ratio, dividend ratio, total share profitability, and dividend profitability. The research findings show that only the priceearnings ratio and total share profitability significantly affect the determination of accounting manipulation, which indicates that companies that want to achieve the predetermined profit targets are more likely to carry out earnings management. The results imply that management has a motive to manipulate financial statements to show the best price-earnings ratio and total share profitability to increase investor confidence. It has an impact on increasing the company's stock price.
\end{abstract}

Keywords: accounting manipulation, investment ratio, financial statement 


\section{Pendahuluan}

Laporan keuangan perusahaan digunakan untuk memberikan informasi tentang keuangan kepada sejumlah kelompok pengguna yang beragam dan memiliki kepentingan masing-masing seperti pemegang saham, kreditor, manajemen perusahaan, dan pemerintah. Tujuan utama dari laporan keuangan adalah memberikan informasi tentang posisi keuangan, arus kas, dan informasi laba (Diah \& Arum, 2013). Laporan keuangan merupakan data pendukung untuk mendapatkan informasi tentang kinerja keuangan sebuah perusahan, sehingga data tersebut bisa dijadikan sebuah dasar untuk membuat keputusankeputusan (Warsadi et al., 2017).

Perusahaan menerbitkan laporan keuangan dengan tujuan ingin memperlihatkan kondisi keuangan dan kinerja perusahaan (Rahmah \& Komariah, 2016). Para pemakai laporan keuangan seperti investor, anggota dewan direksi, kreditor, pemasok memiliki kepercayaan yang penuh terhadap laporan keuangan yang diberikan. Para penyaji laporan keuangan bisa membuat estimasi-estimasi nilai kedepannya untuk membuat keputusan yang bijak (Putranto, 2018). Ketika perusahaan menerbitkan laporan keuangan yang menyimpang dari kondisi ekonomi perusahaan sebenarnya, maka data dari laporan keuangan sudah tidak bisa diandalkan sebagai dasar dari pengambilan keputusan (Gunady \& Mangoting, 2013). Oleh karena itu, laporan keuangan yang dipakai harus bebas dari manipulasi akuntansi supaya bisa mengurangi penyajian informasi yang salah saji secara material. Penyajian informasi laporan keuangan yang netral, lengkap, dan tidak ada unsur manipulasi adalah hak dari semua pengguna laporan keuangan.

Pada laporan keuangan yang terjadi manipulasi akuntansi bisa terdapat informasi yang tidak sesuai dengan kondisi perusahaan. Manipulasi akuntansi dilakukan untuk mencapai tujuan tertentu dengan memperbagus kondisi atau situasi keuangan (Mamo \& Aliaj, 2014). Tindakan manipulasi akuntansi adalah kesalahan akuntansi yang dilakukan dengan sengaja untuk menyesatkan penyaji laporan keuangan (Wells, 2011). Laporan keuangan yang terjadi salah saji informasi laporan keuangan yang material maka akibat yang terjadi adalah data yang didapatkan dari laporan keuangan sudah tidak bisa diandalkan sebagai dasar pembuatan keputusan (Iswati et al., 2012). Oleh karena itu, diperlukan penelitian yang dapat mengindentifikasi manipulasi akuntansi dalam laporan keuangan. Dengan mengetahui cara mengidentifikasi manipulasi akuntansi maka bisa menghindari membuat keputusan yang kurang tepat karena adanya manipulasi akuntansi.

Menurut Beneish (1999) manipulasi akuntansi merupakan tindakan menyalahgunakan data keuangan yang secara sengaja diimplementasikan oleh manajemen perusahaan untuk mencapai tujuan tertentu. Manipulasi akuntansi dilakukan ketika manajemen mendapatkan insentif untuk melakukan manipulasi akuntansi. Manajemen cenderung tidak akan melakukan manipulasi akuntansi jika tidak terdapat insentif ataupun motif bagi manajemen. Manipulasi akuntansi akan dilakukan manajemen jika memiliki insentif atau motif seperti menghindari munculnya angka rugi dari laporan keuangan (Baridwan \& Hariani, 2012). Laporan keuangan yang terjadi manipulasi akuntansi tidak bisa diketahui maupun dideteksi oleh pengguna eksternal. Pengguna eksternal bisa memakai informasi yang diberikan dari laporan keuangan untuk mengetahui kualitas laporan keuangan tersebut. Informasi yang didapatkan dari laporan keuangan bisa dalam berbagai macam rasio sehingga pengguna bisa memakai rasio tersebut untuk melakukan 
berbagai macam analisis untuk menentukan kualitas laporan. Rasio yang dipakai untuk melakukan analisis harus bersifat akrual sehingga bisa mengetahui kondisi perusahaan yang sebenarnya (Gabric, 2018).

Manajemen perusahaan melakukan manipulasi akuntansi untuk memperlihatkan kinerja perusahaan yang bagus. Untuk mencerminkan kinerja perusahaan yang bagus, manajemen perusahaan dapat melakukan manipulasi untuk meningkatkan pendapatan atau laba perusahaan. Laba perusahaan yang tinggi bisa membuat laba per saham perusahaan meningkat. Laba juga berpengaruh pada price earnings ratio dan total share profitability ratio, yang kedua rasio tersebut bisa mencerminkan kinerja perusahaan dalam sisi laba. Laba perusahaan bisa meningkatkan dividen yang dibayar perusahaan, jika dividend ratio makin tinggi maka dividen per saham yang diterima pemegang saham makin tinggi. Dividend profitability ratio merupakan rasio untuk menghitung keefektifan harga saham untuk memperoleh dividen, jika dividend profitability ratio makin tinggi maka kinerja perusahaan makin bagus.

Informasi yang bisa didapatkan investor dari perusahaan yang terdaftar di Bursa Efek Indonesia adalah laporan keuangan. Investor bisa melakukan analisis melalui rasio-rasio keuangan untuk mengidentifikasi manipulasi akuntansi yang terjadi di perusahaanperusahaan tersebut. Perusahaan yang melakukan manipulasi akuntansi telah menyembunyikan kondisi perusahaan yang sebenarnya dari investor. Beberapa perusahaan melakukan manipulasi akuntansi untuk memperbagus laporan keuangan yang diterbitkan perusahaan. Manipulasi akuntansi sering dilakukan manajemen perusahaan untuk menutupi kondisi atau kinerja yang buruk dari perusahaan. Kasus yang terkait tentang manipulasi akuntansi juga terjadi di Indonesia. Pada tahun 2019 Garuda Indonesia yang membesarkan keuntungan atau laba sebesar USD 809 ribu di laporan tahunan 2018. Padahal Garuda Indonesia pada tahun 2017 tersebut sedang mengalami kerugian USD 216.58 juta. Kejadian tersebut diawali dengan Garuda Indonesia memasukkan pendapatan yang seharusnya tidak ada sebesar USD 239.940.000. Tindakan yang dilakukan telah melanggar dari Standar Akuntansi Keuangan (SAK) yang berlaku. Manipulasi akuntansi dilakukan telah dinyatakan sangat material dan bisa menyebabkan salah saji dalam laporan keuangan (Christian et al., 2021).

Tujuan dari penelitian ini adalah untuk menguji pengaruh rasio investasi dalam penentuan manipulasi akuntansi di perusahaan yang terdaftar dalam Bursa Efek Indonesia, dengan memberikan bukti empiris terbaru serta memberikan cara yang praktis kepada pemakai laporan keuangan untuk mendeteksi manipulasi laporan keuangan dengan rasio investasi berbasis akrual. Hasil dari penelitian ini bisa memberikan kontribusi praktis ke pengguna laporan keuangan dalam pengambilan keputusan dengan menganalisis secara cermat laporan keuangan menggunakan rasio investasi akrual.

\section{Kerangka Teoretis Dan Pengembangan Hipotesis}

Manipulasi informasi keuangan adalah penyajian yang terdistorsi, salah saji dari posisi keuangan/kinerja, menciptakan kesan yang salah tentang kekuatan keuangan organisasi. Manipulasi keuangan juga dikenal sebagai revenue management, income smoothing, creative accounting practices, aggressive accounting atau accounting manipulation (Mamo \& Aliaj, 2014). Menurut Standar Audit (SA) seksi 316, manipulasi 
akuntansi dapat melibatkan tindakan seperti berikut ini: (a) manipulasi, pemalsuan, atau perubahan catatan akuntansi atau dokumen pendukung yang digunakan untuk menyusun laporan keuangan; (b) representasi yang keliru, atau penghilangan yang disengajakan dari laporan keuangan tentang informasi-informasi keuangan dan (c) penerapan yang disengaja dari prinsip akuntansi yang berkaitan dengan jumlah, klasifikasi, cara penyajian, atau pengungkapan.

Menurut International Financial Reporting Standards (IFRS), manipulasi akuntansi mencakup laporan keuangan yang mengandung salah saji secara material. Laporan keuangan yang salah saji material telah diatur dalam International Accounting Standards (IAS) bahwa kesalahan material secara individu atau kolektif yang akan mempengaruhi keputusan ekonomi yang dibuat pengguna dengan memakai dasar laporan keuangan. Materialitas bergantung pada kombinasi ukuran dan jenis item laporan keuangan yang dihilangkan atau disajikan secara tidak benar. Kesalahan akuntansi dan kesalahan material timbul dari pengakuan, pengukuran, penyajian, atau pengungkapan elemen laporan keuangan. Alasan terjadinya kesalahan dapat berasal dari kurangnya informasi, penilaian yang salah atas peristiwa bisnis tertentu atau dampak keuangan dari transaksi, kurangnya pengetahuan atau niat untuk menyatakan secara salah.

Perusahaan meningkatkan kinerja kerja dengan mengklasifikasikan aktivitas manipulasi akun keuangan ke dalam dua hubungan aspek risiko (risiko sistematis dan risiko keuangan) dan mengkategorikan aktivitas ini menjadi dua kategori sebagai manajemen laba dan akuntansi kreatif. Creative accounting dan manajemen laba jika diklasifikasikan ke dalam kategori yang berbeda, banyak peneliti dalam literatur mempergunakan kata-kata sinonim. Creative accounting adalah istilah yang lebih disukai di Eropa, sedangkan earning management atau manajemen laba lebih umum digunakan di Amerika Serikat. Istilah lain yang digunakan untuk mewakili manipulasi akun dan digunakan secara sinonim dengan creative accounting atau earnings management, seperti financial engineering, cosmetic accounting, window dressing, innovative accounting or income smoothing (Mamo \& Aliaj, 2014)

Analis, investor, eksekutif senior, dan dewan direksi menganggap laba sebagai item paling penting dalam laporan keuangan yang dikeluarkan oleh perusahaan publik (Clark et al., 2019). Tingkat kepercayaan dari investor ke Chief Executive Officer (CEO) dan Chief Financial Officer (CFO) akan berkurang ketika laba per saham perusahaan tidak mencapai target. Kondisi tersebut membuat manajer memiliki insentif untuk memanipulasi laba demi keuntungan mereka. Adanya kelonggaran yang diperbolehkan dalam akuntansi berbasis akrual relatif terhadap waktu pengakuan pendapatan dan biaya, karena ini manajer memiliki kesempatan yang besar untuk melakukan manajemen laba. Menurut penelitian Omoye (2014), Hadriyanto dan Christiawan (2017) serta Jawabreh et al. (2018) menyatakan bahwa laba per saham mempunyai pengaruh signifikan negatif terhadap penentuan manipulasi akuntansi. Menurut Hadriyanto dan Christiawan (2017) bahwa menurunnya laba per saham akan mengakibatkan penurunan dalam kepercayaan investor karena kinerja perusahaan yang kurang mampu dalam menghasilkan laba per saham yang tinggi. Laba per saham juga rasio yang mencerminkan persepsi investor atas risiko perusahaan. Laba per saham menurun bisa mengakibatkan risiko manajemen dalam melakukan manipulasi akuntansi meningkat, meskipun hasil penelitian Nasution dan 
Nengzih (2020) menyatakan bahwa laba per saham tidak memiliki pengaruh signifikan terhadap penentuan manipulasi akuntansi. Perusahaan yang mempunyai laba yang tinggi tidak menjamin investor bisa mendapatkan tingkat pengembalian yang tinggi karena investor lebih fokus pada pengembalian dividen yang dibagikan dalam bentuk uang tunai. Perusahaan yang membagikan dividen yang tinggi akan lebih meningkatkan kepercayaan investor sehingga perusahaan cenderung akan melakukan manipulasi dividen dibanding melakukan manipulasi laba. Berdasarkan argumentasi tersebut maka diajukan hipotesis sebagai berikut:

$\mathrm{H}_{1}$ : Laba per saham berpengaruh negatif terhadap penentuan manipulasi akuntansi.

Penelitian He et al. (2017) mengartikan bahwa dividen merupakan pembagian laba perusahaan dalam bentuk uang tunai kepada pemegang saham. Jika keuntungan tidak dibagikan kepada pemegang saham dari perusahaan, maka keuntungan tersebut dapat dialihkan oleh orang dalam (insiders) perusahaan untuk penggunaan pribadi atau diarahkan ke investasi yang tidak menguntungkan. Perusahaan yang tidak membayar dividen mungkin mudah mengeksploitasi sumber daya perusahaan untuk kepentingan pribadi. Sebaliknya, di pasar yang tidak sempurna, manajer perusahaan menggunakan dividen sebagai sarana untuk menyelesaikan konflik berbasis agensi antara orang dalam dan pemegang saham luar. Hasil penelitian Caskey dan Hanlon (2013), Fahmi (2016), He et al. (2017), serta Najiyah dan Lahaya (2021) menyatakan bahwa dividen per saham berpengaruh signifikan negatif terhadap penentuan manipulasi akuntansi. Penelitian tersebut menekankan bahwa investor cenderung menginginkan dividen yang rendah yang bertujuan untuk menghindari pajak atas pendapatan tersebut dibandingkan pajak yang dikenakan capital gain. Dengan demikian diajukan hipotesis sebagai berikut:

$\mathrm{H}_{2}$ : Dividen per saham berpengaruh negatif terhadap penentuan manipulasi akuntansi.

Dividen yang dibayarkan kepada pemegang saham bertujuan menghindari laba yang dihasilkan perusahaan untuk penggunaan pribadi dari pihak yang bersangkutan ataupun laba tersebut diinvestasikan ke dalam proyek-proyek yang tidak menguntungkan. Dividen merupakan sebuah perantara untuk menjalin hubungan antara tim manajemen dan pemegang saham. Dividen juga merupakan satu cara untuk mengurangi free cash flow yang dapat dipakai oleh manajer untuk kepentingan pribadi maupun menginvestasi pada projek-projek yang kurang menguntungkan. Dalam penelitian Yulfita (2014), Haini dan Andini (2014), dan Dahayani et al. (2017) menyatakan bahwa tingkat pembayaran dividen dari laba dari perusahaan berpengaruh signifikan negatif dalam penentuan manipulasi akuntansi. Namun penelitian Hasty dan Herawaty (2017) serta Tangestani et al. (2016) menyatakan bahwa tingkat pembayaran dividen dari laba yang didapatkan perusahaan tidak akan berpengaruh dalam penentuan manipulasi akuntansi. Menurut Haini dan Andini (2014) bahwa perusahaan yang memiliki dividend ratio yang tinggi cenderung melakukan manipulasi akuntansi. Hal tersebut diakibatkan oleh kebijakan dividen dari suatu perusahaan mempunyai implikasi yang signifikan dalam pengambilan keputusan investor untuk pembelian saham pada perusahaan. Dengan demikian, berdasarkan argumentasi tersebut diajukan hipotesis sebagai berikut:

$\mathrm{H}_{3}$ : Dividend ratio berpengaruh negatif terhadap penentuan manipulasi akuntansi. 
Pembagian dividen merupakan salah satu cara untuk mengurangi kecurangan. Pembagian dividen bisa mengurangi free cash flow yang ada di perusahaan sehingga bisa menghindari pihak manajemen untuk menginvestasi proyek yang tingkat pengembaliannya kecil dan mengurangi kemungkinan pihak manajemen untuk pemakaian pribadi untuk tujuan tertentu (Barua \& Kumar Saha, 2015). Dividend profitability adalah ratio yang membandingkan dividen perusahaan dengan harga saham perusahaan. Dividend profitability yang semakin rendah berarti dividen yang diterima oleh pemegang saham perusahaan semakin kecil. Manajemen perusahan akan mendapat sanksi ataupun tekanan dari pemegang saham perusahaan jika dividen yang didapatkannya rendah. Dalam penelitian Putri (2015) dan Abelingga et al. (2021) menyatakan bahwa dividen profitability berpengaruh signifikan negatif terhadap penentuan manipulasi laba. Dividend profitability yang semakin rendah berarti dividen yang diterima oleh pemegang saham perusahaan semakin kecil. Pembagian dividen akan mengurangi free cash flow yang ada di perusahaan untuk mengurangi peluang manajemen berinvestasi pada proyek yang kurang menguntungkan ataupun untuk pemakaian pribadi dari pihak manajemen. Namun demikian, penelitian Hartadi Putra et al. (2020) menyatakan bahwa dividend profitability tidak berpengaruh signifikan dalam penentuan manipulasi akuntansi. Hal tersebut disebabkan oleh keputusan pembagian dividen tidak hanya dipengaruhi oleh laba atau rugi perusahaan karena perusahaan juga mempertimbangkan unsur lain berdasarkan Rapat Umum Pemegang Saham (RUPS) dalam menentukan kebijakan dividen. Berdasarkan argumentasi tersebut maka diajukan hipotesis sebagai berikut:

$\mathrm{H}_{4}$ : Dividend profitability berpengaruh negatif terhadap penentuan manipulasi akuntansi.

Penelitian Budhi et al. (2018) menyatakan adanya hubungan antara price earnings ratio dengan harga saham dan laba per saham. Price Earnings Ratio (P/E) banyak digunakan terutama oleh para praktisi sebagai ukuran penilaian saham. Rasio tersebut telah digunakan dalam perbandingan cross-sectional dan time series sebagai metrik untuk menentukan nilai wajar dari saham tersebut. Perusahaan yang tingkat pertumbuhannya tinggi biasanya mempunyai price earnings ratio yang tinggi pula. Hasil penelitian Rahmawantari (2016), Pasaribu et al. (2016) dan Budhi et al. (2018) menyatakan bahwa price earnings ratio berpengaruh signifikan positif terhadap manipulasi akuntansi. Menurut Pasaribu et al. (2016) bahwa nilai perusahaan yang tinggi adalah salah satu motivasi manajemen untuk melakukan manipulasi akuntansi agar penilaian yang terkait dengan kinerja perusahaan akan terlihat bagus dari internal maupun eksternal. Manajemen cenderung melakukan manajemen laba untuk mendukung nilai perusahaan yang sudah baik. Namun penelitian Tabassum et al. (2013) menyatakan bahwa price earnings ratio memiliki pengaruh signifikan negatif terhadap penentuan manipulasi akuntansi. Harga saham perusahaan yang rendah akan mencerminkan kinerja perusahaan yang kurang bagus sehingga perusahaan cenderung melakukan manipulasi akuntansi dalam hal pengurangan beban dan membesarkan nilai penjualan barang dagang ataupun aset tetap. Berdasarkan argumentasi tersebut maka diajukan hipotesis sebagai berikut:

H5: Price earnings ratio berpengaruh positif terhadap penentuan manipulasi akuntansi 
Total share profitability merupakan indikator investasi berbasis akrual yang bisa menunjukkan profitabilitas saham perusahaan (Song et al., 2016). Rasio tersebut melalui indikator profitabilitas dari total modal bisa menunjukkan harga saham yang sebenarnya di perusahaan tersebut. Perusahaan yang memiliki total share profitability rendah menunjukkan bahwa laba yang diperoleh perusahaan semakin rendah. Laba perusahaan yang rendah bisa mengindikasikan bahwa manajemen perusahaan tidak efisien dalam menaikkan kinerja perusahaan. Hasil penelitian Song et al. (2016) dan Gabric (2018) menyimpulkan bahwa total share profitability berpengaruh signifikan negatif terhadap penentuan manipulasi akuntansi. Jika total share profitability semakin rendah maka akan memotivasi manajemen perusahaan untuk melakukan manipulasi akuntansi. Dengan demikian diajukan hipotesis sebagai berikut:

H6: Total share profitability berpengaruh negatif terhadap penentuan manipulasi akuntansi.

\section{Metode Penelitian}

Penelitian ini menggunakan pendekatan kuantitatif yang merupakan penelitian yang terstruktur dan mengkuantifikasikan data untuk dapat digeneralisasikan. Penelitian ini memakai teknik pengumpulan data sekunder dengan menggunakan data perusahaan dari tahun 2015 hingga 2019, yaitu laporan tahunan dan laporan keuangan yang dipublikasikan oleh perusahaan. Data perusahaan tersebut bisa didapatkan langsung dengan melalui situssitus yang tersedia, seperti situs http://www.idx.co.id (Indonesia Stock Exchange) dan situs resmi yang disediakan oleh perusahaan.

Penentuan sampel dalam penelitian ini sejumlah 1978 observasi menggunakan teknik purposive sampling, dengan kriteria sebagaimana disajikan pada Tabel 1 berikut ini:

Tabel 1. Perhitungan Sampel

\begin{tabular}{clc}
\hline No. & \multicolumn{1}{c}{ Kriteria Pemilihan Sampel } & Jumlah \\
\hline 1 & Perusahaan yang terdaftar di Bursa Efek Indonesia pada tahun 2015-2019 & 511 \\
2 & Perusahaan yang bergerak di sektorkeuangan & $(105)$ \\
3 & Perusahaan yang telah memenuhi kriteria sampel (406 x 5 tahun) & 2030 \\
4 & Data outlier & $\underline{(52)}$ \\
& Jumlah sampel & 1978 \\
\hline
\end{tabular}

Variabel dependen dalam penelitian ini adalah penentuan manipulasi akuntansi, yang merupakan tindakan dengan sengaja mengubah informasi di laporan keuangan sehingga informasi yang disampaikan oleh penyaji laporan keuangan tidak mencerminkan keadaan sebenarnya (Hastuti \& Gozali, 2015). Dalam penelitian ini, perusahaan yang terdeteksi manipulasi akuntansi diberikan nilai 1 dan tidak terdeteksi manipulasi akuntansi dengan memberikan nilai 0. Berdasarkan Alaryan et al. (2014) penentuan manipulasi akuntansi dengan memakai 2 cara yaitu: (1) jika laporan audit memberikan opini atas keraguan serius atas kebenaran akun tersebut dan (2) jika laporan keuangan ditolak oleh otoritas pajak. Adapun, variabel independen yang diuji dalam penelitian ini adalah laba per saham, dividen per saham, price earnings ratio, dividend ratio, total share profitability dan dividend profitability. Pengukuran variabel dari masing-masing variabel independen dalam penelitian ini dijelaskan sebagai berikut: 
Laba per saham mengacu pada persentase laba perusahaan yang dibagi ke masing-masing saham yang beredar. Laba per saham merupakan cara pengukuran dari indikator kinerja yang dilaporkan oleh manajemen perusahaan kepada pemegang saham (shareholders), pasar dan pihak yang berkepentingan (Nadilla et al., 2019). Perhitungan laba per saham adalah sebagai berikut:

$$
\text { Laba per saham }=\frac{\text { Laba bersih }}{\text { Rata }- \text { rata saham beredar }}
$$

Dividen per saham menunjukkan kemampuan perusahaan untuk mendistribusikan beberapa laba yang didapatkan perusahaan kepada pemegang saham (shareholder) berdasarkan jumlah saham yang dipegang. Dividen per saham mengacu pada jumlah dividen yang dibayar dan rasio ini memiliki pengaruh signifikan terhadap harga pasar saham (He et al., 2017). Perhitungan deviden per saham adalah sebagai berikut:

$$
\text { DPS }=\frac{\text { Dividen }}{\text { Rata }- \text { rata saham beredar }}
$$

Price Earnings Ratio menunjukkan hubungan antara harga saham di pasar dan laba per saham. Price earnings ratio digunakan analis pasar dan calon investor sebagai indikator dari nilai pasar perusahaan. Price earnings ratio $(\mathrm{P} / \mathrm{E})$ dihitung dengan membandingkan harga saham dipasar dengan laba per saham (Tabassum et al., 2013) sebagai berikut:

$$
P / E=\frac{\text { Share market price }}{\text { Earning per Shares }}
$$

Dividen sebagai bagian dari pendapatan yang mewakili kondisi keuangan perusahaan saat ini. Dividen merupakan salah satu cara untuk mengetahui efisiensi manajemen perusahaan dalam memanfaatkan sumber daya keuangan dalam memperoleh keuntungan. Dividend ratio menunjukkan persentase laba yang di distribusikan perusahaan kepada shareholders atau pemegang saham dalam bentuk uang tunai. Dividend ratio merupakan besar persentase laba per saham perusahaan yang dapat diganti menjadi uang tunai (Hasty \& Herawaty, 2017) yang dihitung sebagai berikut:

$$
\text { Dividend Ratio }=\frac{\text { Dividend per Shares }}{\text { Earning per Shares }}
$$

Total Share Profitability menunjukkan efisiensi perusahaan untuk laba per saham setiap tahun kepada pemegang saham (shareholders). Total share profitability membandingkan laba per saham perusahaan dengan harga saham perusahaan di pasar. Total share profitability menunjukkan persentase laba yang bisa didapatkan dari harga saham perusahaan (Gabric, 2018), yang dihitung sebagai berikut:

$$
\text { Total Share Profitability }=\frac{\text { Earnings per Share }}{\text { Shares Market Prices }}
$$


Dividend Profitability menunjukkan hasil perusahaan membayar dividen setiap tahun kepada pemegang saham (shareholders). Dividend profitability mengukur pendapatan yang diterima dalam bentuk kas atau aset lainnya dengan harga saham di pasar (Abelingga et al.,2021), yang dihitung dengan cara sebagai berikut:

$$
\text { Dividend Profitability }=\frac{\text { Dividend per Shares }}{\text { Shares Market Prices }}
$$

Penelitian ini menggunakan data yang bersifat time series, yaitu merupakan teknik pengambilan data pada interval waktu tertentu (Anshori \& Iswati, 2019). Alat analisis pada penelitian ini adalah menggunakan analisis regresi logistik untuk melakukan pengujian hipotesis menggunakan persamaan regresi logistik sebagai berikut:

$$
\operatorname{Ln} \frac{p}{1-p}=\beta_{0}+\beta_{1} \text { EPS }+\beta_{2} \text { DPS }+\beta_{3} \text { PER }+\beta_{4} \text { DivRatio }+\beta_{5} \text { TOTSharProb }+\beta_{6} \text { DivProb }+\mathrm{e}
$$

Keterangan :

$\begin{array}{ll}\text { EPS } & =\text { Laba per saham } \\ \text { DPS } & =\text { Dividen per saham } \\ \text { PER } & =\text { Price Earnings Ratio } \\ \text { DivRatio } & =\text { Dividend Ratio } \\ \text { TOTSharProb } & =\text { Total Share Profitability } \\ \text { DivProb } & =\text { Dividend Profitability } \\ \beta_{0} & =\text { Dividend Profitability } \\ \beta_{1}, \beta_{2}, \beta_{3}, \beta_{4} \beta_{5}, \beta_{6} & =\text { Dividend Profitability } \\ \mathrm{e} & =\text { error }\end{array}$

\section{Hasil dan Pembahasan}

Statistik deskriptif dalam penelitian ini memberikan gambaran yang berkaitan dengan nilai minimum, maksimum, rata-rata, standard deviasi, dan frekuensi dari data penelitian. Total data pengujian dapat dilihat dari kolom $\mathrm{N}$ dengan jumlah observasi yang dipakai sebanyak 1978. Pada kolom variabel menunjukkan variabel independen dan dependen yang diuji sebagaimana disajikan pada Tabel 2 berikut ini:

\begin{tabular}{|c|c|c|c|c|c|}
\hline Variabel & $\mathbf{N}$ & Minimum & Maksimum & Rata-Rata & $\begin{array}{c}\text { Standard } \\
\text { Deviasi }\end{array}$ \\
\hline EPS & 1978 & $-2270,37$ & 3032,61 & 76,7164 & 282,9296 \\
\hline DPS & 1978 & 0,00 & 835,00 & 28,1982 & 86,2507 \\
\hline PER & 1978 & $-2500,00$ & 3517,51 & 26,2912 & 221,5117 \\
\hline DivRatio & 1978 & $-48,31$ & 14,00 & 0,1552 & 1,2465 \\
\hline TOTSharProb & 1978 & $-4,62$ & 4,90 & $-0,0147$ & 0,4727 \\
\hline DivProb & 1978 & 0,00 & 0,53 & 0,0139 & 0,330 \\
\hline \multicolumn{3}{|l|}{ Variabel } & $\mathbf{N}$ & Persentase & Frekuensi \\
\hline \multicolumn{2}{|c|}{ Manipulasi akuntansi } & \multicolumn{2}{|r|}{1978} & $2,1 \%$ & 41 \\
\hline \multicolumn{2}{|c|}{ Tidak terjadi manipulasi akuntansi } & \multicolumn{2}{|r|}{1978} & $97,9 \%$ & 1937 \\
\hline
\end{tabular}

Tabel 2. Ringkasan Hasil Uji Statistik Deskriptif 
Berdasarkan Tabel 2 menunjukkan nilai laba per saham sebagai pengukuran dari indikator kinerja yang dilaporkan oleh manajemen perusahaan kepada pemegang saham, pasar, dan pihak yang berkepentingan. Nilai minimum sebesar $-2270,37$ atau senilai Rp. $-2.270,37$ memiliki arti bahwa capaian kinerja perusahaan tersebut kurang. Hasil tersebut menjelaskan bahwa pemegang saham telah mengalami kerugian berdasarkan jumlah saham yang dipegang. Nilai saham dari perusahaan akan mengalami penurunan seiring dengan terjadinya kerugian, hal tersebut mengakibatkan pemegang saham akan terjadi capital loss. Nilai maksimum sebesar 3032,61 atau senilai Rp.3.032,61 memiliki arti bahwa kinerja perusahaan itu cukup bagus dalam memperoleh laba perusahaan. Nilai rata-rata 76,7164 atau senilai Rp.76,7164 yang berarti bahwa sebagian besar kinerja perusahaan masih dalam kondisi bagus dengan mendapat hasil laba per saham positif, hasil positif mengartikan bahwa perusahaan tersebut dalam kondisi laba.

Dividen per saham menunjukkan kemampuan perusahaan untuk mendistribusikan beberapa laba yang didapatkan perusahaan kepada pemegang saham berdasarkan jumlah saham yang dipegang. Nilai minimum sebesar 0,00 menunjukkan perusahaan tersebut tidak mengalokasikan laba dalam bentuk uang tunai kepada pemegang saham sehingga hasil tersebut menunjukkan Rp.0 per saham. Berdasarkan Pasal 71 ayat (2) Undang-Undang Nomor 40 Tahun 2007 tentang Perseroan Terbatas menjelaskan bahwa perusahaan yang mengalami defisit atau saldo laba negatif tidak diperbolehkan membagikan dividen. Hal tersebut menyebabkan kebanyakan perusahaan tidak bisa membagikan dividen karena mengalami defisit. Nilai maksimum sebesar 835,00 berarti perusahaan tersebut mengalokasikan laba dalam bentuk uang tunai kepada pemegang saham sebesar Rp.835 per lembar saham, hal ini menunjukkan bahwa perusahaan tersebut memiliki kinerja yang bagus sehingga bisa membagikan dividen dalam jumlah besar. Nilai rata-rata 28,1982 yang berarti bahwa mayoritas perusahaan membayar dividen sebesar Rp.28,1982 per lembar saham kepada pemegang saham.

Price earnings ratio (PER) menunjukkan hubungan antara harga saham dipasar dan laba per saham. Price earnings ratio digunakan analis pasar dan calon investor sebagai indikator penilaian nilai pasar perusahaan dalam kondisi normal ataupun tidak normal. Nilai minimum sebesar -2500,00 menunjukkan bahwa perusahaan tersebut dalam kondisi rugi atau defisit. Perusahaan yang mendapatkan PER negatif akan menurunkan tingkat investasi dari investor ke perusahaan yang bisa menyebabkan nilai saham di pasar akan menurun. Nilai maksimum sebesar 3517,51 menunjukkan bahwa perusahaan tersebut dalam kondisi kinerja yang bagus dan nilai perusahaan tersebut juga dalam kondisi bagus. Nilai rata-rata sebesar 26,2912 berarti sebagian besar perusahaan dalam kondisi laba dan nilai perusahaan dalam kondisi bagus.

Dividend ratio menunjukkan persentase laba perusahaan yang didistribusikan kepada shareholders atau pemegang saham dalam bentuk uang tunai. Nilai minimum sebesar -48,31 menunjukkan bahwa perusahaan dalam kondisi kinerja tidak bagus dan telah memperoleh kerugian, namun perusahaan tidak mengalami saldo laba negatif atau defisit sehingga perusahaan tersebut boleh melakukan pembagian dividen. Perusahaan yang mengalami kerugian namun tetap membagikan dividen bisa mengartikan bahwa perusahaan mempunyai free cash flow yang besar untuk mendukung pembayaran dividen. Nilai maksimum dividend ratio sebesar 14,00 dan nilai minimum $-48,31$. Nilai rata-rata 
sebesar 0,1552 menunjukkan bahwa mayoritas perusahaan sampel masih membayar $15,52 \%$ untuk deviden dari total laba yang diperoleh pada tahun berjalan tersebut.

Total share profitability menunjukkan persentase laba yang bisa didapatkan dari harga saham perusahaan. Nilai minimum -4,62 menunjukkan bahwa perusahaan tersebut dalam kondisi rugi yang menunjukkan bahwa nilai saham yang diinvestasikan untuk memperoleh laba telah mencapai hasil negatif (minus). Hasil minus tersebut mengakibatkan pemegang saham mendapatkan capital loss dari tindakan investasi tersebut. Capital loss yang dialami pemegang saham dapat mendorong untuk melakukan tindakan cut loss untuk menghindari mendapatkan kerugian yang lebih banyak. Dengan demikian nilai saham di pasar akan mengalami penurunan yang besar akibat dari penurunan laba tersebut. Nilai maksimum 4,90 bisa diartikan bahwa perusahaan tersebut dalam kondisi kinerja yang bagus dan mendapatkan laba, hasil tersebut juga menunjukkan total laba yang diperoleh per lembar saham telah mencapai $490 \%$ dari nilai per lembar saham. Nilai ratarata $-0,0147$ bisa diartikan bahwa mayoritas pada perusahaan sampel telah mengalami kerugian dari per lembar saham sebesar $1,47 \%$.

Dividend profitability mengukur pendapatan yang diterima dalam bentuk uang tunai atau aset lainnya dengan harga saham di pasar. Nilai minimum 0,00 menunjukkan bahwa perusahaan tersebut tidak melakukan pembagian dividen sehingga tidak ada pengembalian laba dalam bentuk uang tunai dari harga saham yang beredar di pasar. Sesuai dengan Pasal 71 ayat (2) Undang-Undang Nomor 40 Tahun 2007 tentang Perseroan Terbatas yang menyatakan bahwa perusahaan telah mengalami saldo laba negatif sehingga tidak boleh membagikan dividen, atau perusahaan telah mempunyai saldo laba positif namun tidak mempunyai free cash flow yang besar untuk mendukung pembayaran dividen. Nilai maksimum 0,53 dapat diartikan perusahaan tersebut mempunyai pengembalian laba dalam bentuk uang tunai yang sangat besar dari harga saham yang beredar dipasar. Nilai rata-rata 0,0139 berarti perusahaan membayar dividen dari total harga saham sebesar 1,39\%.

Hasil statistik deskriptif terhadap manipulasi akuntansi yang merupakan variabel dependen menggunakan skala kategori. Pengujian tersebut untuk mengetahui frekuensi terjadi manipulasi akuntansi atau tidak terjadinya dalam laporan keuangan perusahaan yang terdapat di Bursa Efek Indonesia. Manipulasi akuntansi merupakan variabel dummy dari penelitian ini, hasil 1 menunjukkan bahwa laporan keuangan telah terjadi manipulasi akuntansi dan hasil 0 menunjukkan bahwa laporan tersebut tidak terjadi manipulasi akuntansi. Laporan keuangan yang dimanipulasi dan tidak dimanipulasi dikategorikan dengan menggunakan laporan audit independen. Hasil audit yang menunjukkan opini wajar tanpa pengeculian maka dikategorikan sebagai laporan keuangan yang tidak melakukan manipulasi akuntansi, sedangkan opini audit yang selain itu maka dikategorikan sebagai laporan keuangan yang telah terjadi manipulasi akuntansi. Dari hasil di atas bisa diartikan bahwa dari total 1978 data yang dikumpulkan, dapat diidentifikasi terjadi manipulasi akuntansi sebanyak 41 laporan keuangan atau sebesar 2,1\%. Laporan keuangan yang tidak terjadi manipulasi akuntansi sebesar 97,9\% dari 1978 observasi atau sebanyak 1937 laporan keuangan. Laporan audit independen mengeluarkan opini dengan menggunakan Pernyataan Standar Akuntansi Keuangan (PSAK) sebagai standar untuk memeriksa laporan keuangan dari suatu perusahaan. Hasil yang didapatkan bisa menjelaskan bahwa sebagian besar perusahaan telah mematuhi PSAK yang berlaku. 
Perusahaan yang menaati PSAK tidak dikategorikan sebagai perusahaan yang melakukan manipulasi akuntansi.

Pengujian hasil uji R square bertujuan mengetahui persentase kecocokan model pada penelitian sebagaimana disajikan pada Tabel 3 menunjukkan nilai lebih dari 0,157 sehingga dapat dinyatakan bahwa model penelitian tersebut hanya mampu menjelaskan variabel dependen sebesar 15,7\%; sedangkan sisanya 84,3\% lainnya dijelaskan oleh faktorfaktor lain yang diluar dalam model penelitian yang dispesifikasikan ini. Hasil uji Hosmer and Lemeshow menunjukkan kesesuaian atau ketepatan model penelitian (goodness of fit) terhadap data yang dikumpulkan. Hal ini ditunjukkan oleh nilai signifikansi Hosmer and Lemeshow sebesar 0,797 yang lebih besar dari 0,05 sehingga dapat dikatakan model yang dibentuk sudah sesuai.

Tabel 3. Ringkasan Hasil Uji Regresi Logistik

\begin{tabular}{lccc}
\hline \multicolumn{1}{c}{ Variabel } & Koefisien & Prob. & Kesimpulan \\
\hline Constant & $-3,439$ & 0,000 & \\
EPS & $-0,001$ & 0,398 & Tidak Signifikan \\
DPS & $-0,752$ & 0,991 & Tidak Signifikan \\
PER & $-0,001$ & 0,046 & Signifikan Negatif \\
DivRatio & $-27,190$ & 0,972 & Tidak Signifikan \\
TOTSharProb & $-0,518$ & 0,019 & Signifikan Negatif \\
DivProb & $-41,993$ & 0,979 & Tidak Signifikan \\
\hline Uji R & $=$ & 0,157 & \\
Uji Hosmer and Lemeshow & $=$ & 0,797 & \\
\hline
\end{tabular}

Hasil pengujian signifikansi parameter individual (uji t) pada Tabel 3, menjelaskan bahwa variabel independen laba per saham, dividen per saham, dividend ratio, dan dividend profitability memiliki nilai probability lebih dari 0,05 sehingga dapat disimpulkan tidak berpengaruh secara signifikan terhadap variabel dependen manipulasi akuntansi. Variabel price earnings ratio (PER) dan total share profitability mendapatkan nilai probability lebih kecil dari 0,05 sehingga memiliki pengaruh signifikan dengan arah koefisien negatif terhadap terhadap manipulasi akuntansi. Dengan hasil penelitian ini mendukung hipotesis 3 dan 5, namun hipotesis 1, 2, 4 dan 6 tidak dapat didukung.

Dari hasil uji $t$ membuktikan bahwa laba per saham tidak mempunyai pengaruh signifikan terhadap manipulasi akuntansi. Dari tabel 3 menyatakan bahwa laba per saham menunjukkan hasil probabilitas 0,398 dan koefisien -0,001. Hasil ini menyatakan bahwa laba per saham tidak berpengaruh signifikan terhadap penentuan manipulasi akuntansi. Laba per saham merupakan salah satu rasio keuangan untuk mengetahui kinerja dari sebuah perusahaan. Perusahaan mendapatkan nilai laba per saham yang tinggi menandakan laba yang diperoleh dari perusahaan tersebut juga tinggi dan mencerminkan kinerja perusahaan yang bagus. Manajemen dapat menggunakan fleksibilitas yang dimilikinya untuk melakukan manipulasi akuntansi seperti manajemen laba yang tidak menyimpang dari standar akuntansi yang berlaku dan hukum yang berlaku. Manajemen lebih memilih memperlihatkan kinerja yang secara terus menerus terlihat makin baik dibanding hanya lebih baik di satu titik waktu tertentu saja. Hasil penelitian ini sejalan dengan hasil studi Nasution dan Nengzih (2020) bahwa laba per saham tidak berpengaruh signifikan terhadap manipulasi akuntansi. Namun, hasil penelitian ini kontradiktif dengan penelitian Omoye 
(2014), Hadriyanto dan Christiawan (2017) serta Jawabreh et al. (2018) yang menyatakan bahwa laba per saham berpengaruh signifikan negatif terhadap manipulasi akuntansi.

Dividen per saham (DPS) tidak mempunyai pengaruh signifikan dalam penentuan manipulasi akuntansi. Sesuai dengan hasil yang tertera di Tabel 3 menyatakan bahwa DPS menunjukkan hasil probabilitas 0,991 dan koefisien -0,752. Hasil ini menyatakan bahwa DPS tidak berpengaruh signifikan terhadap penentuan manipulasi akuntansi, yang berarti besar ataupun kecilnya DPS tidak berkontribusi terhadap penentuan manipulasi akuntansi. Hal tersebut disebabkan oleh sebagian besar dari perusahaan tidak membagikan dividen. Hal ini dilandasi oleh regulasi dalam Pasal 71 ayat (2) Undang-Undang Nomor 40 Tahun 2007 tentang Perseroan Terbatas yang mengatur perusahaan yang mengalami saldo negatif tidak boleh membagi dividen. Argumentasi lain juga diakibatkan oleh perusahaan yang mengalami keuntungan namun tidak mempunyai free cash flow yang cukup besar untuk melakukan pembagian dividen. Dengan demikian, hasil penelitian ini tidak sejalan dengan penelitian dari Caskey dan Hanlon (2013) dan He et al. (2017) yang mendapatkan hasil pengaruh signifikan negatif DPS terhadap manipulasi akuntansi.

Berdasarkan hasil pengujian pada Tabel 3 menunjukkan bahwa variabel Price Earnings Ratio (PER) menunjukkan pengaruh signifikan negatif terhadap manipulasi akuntansi. Dari hasil uji $t$ menunjukkan nilai signifikasi dari PER sebesar 0,046 dengan nilai koefisien menunjukkan nilai -0,001. Hasil ini menyatakan bahwa PER berpengaruh signifikan negatif terhadap penentuan manipulasi akuntansi, yang berarti semakin kecil PER berkontribusi dalam penentuan manipulasi akuntansi. Hal tersebut diakibatkan karena laporan keuangan yang mendapatkan opini selain dari wajar tanpa pengecualian akan menurunkan kepercayaan investor terhadap perusahaan tersebut, yang dapat menyebabkan harga saham dari perusahaan akan menurun dari harga semula. Hasil penelitian ini sejalan dengan penelitian Tabassum et al. (2013) yang menyatakan pengaruh signifikan negatif PER terhadap manipulasi akuntansi. Namun hasil penelitian tidak sejalan dengan hasil penelitian Rahmawantari (2016), Pasaribu et al. (2016), dan Budhi et al. (2018) yang menyatakan adanya pengaruh signifikan positif PER terhadap manipulasi akuntansi.

Hasil pengujian lainnya membuktikan bahwa dividend ratio tidak mempunyai pengaruh signifikan terhadap manipulasi akuntansi. Nilai yang didapatkan dari hasil pengujian menyatakan bahwa dividend ratio menunjukkan hasil probabilitas 0,972 dan koefisien -27,190. Hasil ini menyatakan bahwa dividend ratio tidak berpengaruh signifikan terhadap penentuan manipulasi akuntansi, yang berarti semakin besar atau kecilnya pengembalian dividen dari laba per saham tidak berkontribusi terhadap penentuan manipulasi akuntansi. Secara garis besar investor berfokus dalam tingkat pengembalian dalam berinvestasi. Pengembalian dari perusahaan bisa berupa dividen maupun capital gain. Investor tidak berpengaruh dari pembagian laba dari perusahaan yang berupa uang tunai maupun berupa laba ditahan. Dengan demikian manipulasi akuntansi dalam tingkat pembagian dividen tidak dapat memengaruhi investor. Hasil penelitian ini sejalan dengan studi Hasty dan Herawaty (2017) serta Tangestani et al. (2016). Namun hasil penelitian ini tidak sejalan dengan Yulfita, (2014), Haini dan Andini (2014) serta Dahayani et al. (2017).

Nilai signifikasi dari total share profitability sebesar 0,019 lebih kecil daripada 0,05 dan koefisien regresi menunjukkan nilai -0,518. Hasil ini menyatakan bahwa total share profitability berpengaruh signifikan negatif terhadap penentuan manipulasi akuntansi, yang 
berarti semakin kecilnya total share profitability akan berkontribusi terhadap penentuan manipulasi akuntansi. Hal tersebut disebabkan oleh rendahnya harga saham di pasar yang membuat tim manajemen mendapat tekanan sehingga melakukan manipulasi akuntansi dalam penyajian kinerja perusahaan. Hasil penelitian ini sejalan dengan penelitian Song et al. (2016) dan Gabric (2018). Hasil pengujian lainnya menunjukkan dividend profitability tidak mempunyai pengaruh signifikan terhadap manipulasi akuntansi yang ditunjukkan oleh probabilitas 0,978 lebih besar dari 0,05 dan koefisien -41,993. Hasil ini menjelaskan investor dapat memperoleh pengembalian melalui dividen dan capital gain. Adanya pengembalian capital gain membuat investor tidak lagi mengejar dividen untuk mendapat pengembalian. Dengan demikian manajemen tidak perlu memanipulasi akuntansi untuk pembagian dividen yang bertujuan untuk menaikkan kepercayaan investor terhadap kinerja perusahaan. Hasil ini sejalan dengan studi Hartadi Putra et al. (2020), namun kontradiktif dengan penelitian Putri (2015) dan Abelingga et al. (2021) yang menyatakan pengaruh signifikan negatif dividend profitability terhadap manipulasi akuntansi.

\section{Kesimpulan, Implikasi dan Keterbatasan}

Hasil penelitian menyatakan bahwa price earnings ratio dan total share profitability berpengaruh signifikan negatif terhadap penentuan manipulasi akuntansi. Namun demikian, manipulasi akuntansi tidak dipengaruhi secara signifikan oleh laba per saham, dividen per saham, dividend ratio, dan dividend profitability. Temuan penelitian ini mengindikasikan bahwa manajemen memiliki motif untuk melakukan manipulasi terhadap laporan keuangan untuk bisa menunjukkan nilai price earnings ratio dan total share profitability yang paling bagus kepada investor. Jika investor mendapat nilai price earnings ratio dan total share profitability yang buruk maka kepercayaannya akan menurun dan bisa mengakibatkan harga saham perusahaan tersebut menurun. Namun demikian, dividen bukan merupakan satu-satunya jenis pengembalian yang diharapkan investor, karena investor juga memandang capital gain sebagai tolok ukur pengembalian dari investasi. Investor memperdulikan tingkat pengembalian dari sebuah investasi, namun tidak membedakan jenis pengembalian yang berupa uang tunai ataupun laba ditahan. Temuan penelitian ini mengimplikasikan tentang pentingnya pengguna laporan keuangan untuk menganalisis adanya manipulasi akuntansi dalam laporan keuangan melalui analisis dengan berbagai rasio laporan keuangan. Analisis yang kompleks dan cerdas akan mengurangi potensi salah saji laporan keuangan secara material. Pengujian penelitian ini terbatas pada Bursa Efek Indonesia, sehingga penelitian selanjutnya dapat memperluas pengambilan sampel ke bursa efek negara lain maupun dengan pengujian pada sektor yang berbeda seperti sektor keuangan karena memiliki regulasi yang ketat dibanding dengan sektor non keuangan. Sebagian besar perusahaan dari BEI tidak melakukan pembagian dividen kepada pemegang saham, sehingga hasil penelitian dalam hal yang terkait dengan dividen menjadi terbatas. Penelitian ini hanya memakai beberapa macam rasio sebagai indikator dalam penentuan manipulasi akuntansi dan untuk penelitian selanjutnya dapat menguji rasio seperti profitability ratio, solvency ratio, activity ratio, cash flow ratio, dan liquidity ratio untuk bisa menguji laporan keuangan secara keseluruhan dan bisa mendeteksi indikator-indikator lainnya yang mempengaruhi penentuan manipulasi akuntansi. 


\section{Daftar Pustaka}

Abelingga, D., Puspa Midiastuty, P., Suranta, E., \& Indriani, R. (2021). Deteksi fraudulent financial reporting: suatu pendekatan menggunakan accrual based investment ratio dan cash based investment ratio. Jurnal Akuntansi, Keuangan, Dan Manajemen, 2(2), 115-128. https://doi.org/10.35912/jakman.v2i2.203

Alaryan, L. A., Abu Haija, A. A., \& Alrabei, A. M. (2014). The relationship between fair value accounting and the presence of manipulation in financial statements. International Journal of Accounting and Financial Reporting, 4(1), 221-237. https://doi.org/10.5296/ijafr.v4i1.5405

Anshori, M., \& Iswati, S. (2019). Metodologi penelitian kuantitatif: edisi 1. Airlangga University Press.

Baridwan, Z., \& Hariani, A. R. (2012). Insentif untuk memanipulasi laba sebagai syarat keefektifan audit yang berkualitas dalam mengurangi manipulasi akuntansi (Indonesian). SSRN Electronic Journal. https://doi.org/10.2139/ssrn.1577796

Beneish, M. D. (1999). The detection of earnings manipulation. Financial Analysts Journal, 55(5), 24-36. https://doi.org/10.2469/faj.v55.n5.2296

Budhi, S., Rahmawan, T. D. M., \& Cahyo, U. F. (2018). Effect of stock price, debt to equity ratio, return on assets, earning per share, price earning ratio, and firm size on income smoothing in Indonesia manufacturing industry. Russian Journal of Agricultural and Socio-Economic Sciences, 78(6), 290-297. https://doi.org/10.18551/rjoas.2018-06.33

Caskey, J., \& Hanlon, M. (2013). Dividend policy at firms accused of accounting fraud. Contemporary Accounting Research, 30(2), 818-850. https://doi.org/10.1111/j.19113846.2012.01173.x

Christian, N., Jessica, \& Rionaldo, L. (2021). Pendeteksian financial shenanigans pada laporan keuangan PT Garuda Indonesia Tbk. Jurnal Maneksi, 10(1), 66-75. https://doi.org/https://doi.org/10.31959/jm.v10i1

Dahayani, N. K. S., I Ketut Budiartha, B., \& Suardikha, I. M. (2017). Pengaruh kebijakan dividen pada manajemen laba dengan Good Corporate Governance sebagai moderasi. E-Jurnal Ekonomi Dan Bisnis Universitas Udayana, 6(4), 1395-1424.

Diah, E., \& Arum, P. (2013). Implementation of International Financial Reporting Standards ( IFRS ) and the quality of financial statement information in Indonesia. Research Journal of Finance and Accounting, 4(19), 200-210.

Fahmi, I. (2016). Pengaruh dividen per share, return on equity dan net profit margin terhadap harga saham perusahaan manufaktur di Bursa Efek Indonesia. Jurnal Ilmiah Mahasiswa Ekonomi Manajemen, 1(2), 158-173. DOI: https://doi.org/10.24815/jimen.v1i2.861

Gabric, D. (2018). Determination of accounting manipulations in the financial statements using accrual-based investment ratios. Economic Review: Journal of Economics and Business, 16(1), 71-81. http://hdl.handle.net/10419/193884

Gunady, F., \& Mangoting, Y. (2013). Faktor-faktor yang mempengaruhi keputusan perusahaan manufaktur yang terdaftar di BEI tahun 2008-2012 melakukan pergantian 
kantor akuntan publik. Tax \& Accounting Review, 3(2), 1-13.

Hadriyanto, I., \& Christiawan, J. (2017). Pengaruh kondisi laba operasional terhadap manajemen laba. Business Acounting Review, 5(1), 37-48.

Haini, S. N., \& Andini, P. (2014). Pengaruh Return On Asset (ROA), Dividend Payout Ratio (DPR), Debt To Equity Ratio (PER), dan kepemilikan institusional terhadap praktik perataan laba. Jurnal Akuntansi Dan Keuangan, 3(1), 186-198.

Hartadi Putra, D., Wangsadharma, N., Ariati Hidayat, A., \& Adelina, Y. E. (2020). Pengaruh manajemen laba terhadap kebijakan dividen di Indonesia. Ekonomi Dan Bisnis, 7(1), 52-74. https://doi.org/10.35590/jeb.v7i1.1430

Hastuti, T. D., \& Gozali, I. (2015). Manipulation detection in financial statements. International Journal of Humanities and Management Sciences, 3(4), 222-229.

Hasty, A. D., \& Herawaty, V. (2017). Pengaruh struktur kepemilikan, leverage, profitabilitas dan kebijakan dividen terhadap manajemen laba dengan kualitas audit sebagai variabel moderasi. Media Riset Akuntansi, Auditing \& Informasi, 17(1), 1-16. https://doi.org/10.25105/mraai.v17i1.2023

He, W., Ng, L., Zaiats, N., \& Zhang, B. (2017). Dividend policy and earnings management across countries. Journal of Corporate Finance, 42, 267-286. https://doi.org/10.1016/j.jcorpfin.2016.11.014

Indriantoro, N., \& Supomo, B. (2013). Metodologi Penelitian Bisnis untuk Akuntansi \& Manajemen. BPFE-Yogyakarta.

Iswati, S., Iswahjuni, \& Windijarto. (2012). Mengungkap kendala yang dihadapi auditor dalam mendeteksi kecuranganan salah saji material pada laporan keuangan historis (studi terhadap pengaruh perubahan pola pikir dari "rule based" menjadi "principle based" dalam audit laporan keuangan historis). Jurnal Ekonomi dan Bisnis Airlangga, 3(22), 215-229. http://dx.doi.org/10.20473/jeba.V22I32012.\%25p.

Jawabreh, O., Bader, A., Mahmoud, A., \& Alrabei, A. (2018). Fraud inference investigation within the tourism sector in Jordan fraud inference investigation within the tourism sector in Jordan. Journal of Economic \& Management Perspectives, $12(1), 5-20$.

Clark.S, C.E. Jordan., V. C. Simmons. (2019). Earnings management to round Up EPS a penny: Testing for an audit quality differential between big four and non-big four accounting firms. Journal of Forensic and Investigative Accounting, 11(3), 503-523.

Mamo, J., \& Aliaj, A. (2014). Accounting manipulation and its effects on the financial statements of Albanian entities. Interdisciplinary Journal of Research and Development, 1(2), 55-60.

Nadilla, T., Ulfah, A. K., Hayati, H., Midesia, S., \& Puspita, D. (2019). The effect of leverage and earning per share on earnings management (A study of companies listed in the Indonesia stock exchange). In ICASI 2019: Proceedings of The 2nd International Conference On Advance And Scientific Innovation, Banda Aceh, Indonesia, 164(1), 1-6.

Najiyah, F., \& Lahaya, I. A. (2021). Pengaruh dividend per share dan return on equity serta net profit margin terhadap harga saham pada perusahaan sektor property, real estate dan building construction yang terdaftar di Bursa Efek Indonesia. Akuntabel, 18(1), 
$63-71$.

Nasution, F. A., \& Nengzih, N. (2020). The influence of Good Corporate Governance, earnings per share, and the characteristic of the company on earnings management (Case Study at Banking go public Companies Listed on Indonesia Stock Exchange 2015-2018). Saudi Journal of Business and Management Studies, 5(7), 406-417. https://doi.org/10.36348/sjbms.2020.v05i07.005

Nasution, M., \& Setiawan, D. (2007). Pengaruh corporate governance terhadap manajemen laba di industri perbankan Indonesia. Simposium Nasional Akuntansi X, 1(1), 1-26.

Omoye, A . L., \& Eragbhe, E. (2014). Accounting ratio and false financial statements detection: Evidence from Nigerian Quoted Companies. International Journal of Business and Social Science, 7(1), 207-215.

Pasaribu, R., Kowanda, D., \& Widyastuty, E. (2016). Pengaruh konservatisme akuntansi, kepemilikan manajerial, kebijakan dividen, ukuran perusahaan, leverage, price earning ratio, price to book value dan earning per share terhadap manajemen laba (Studi pada emiten manufaktur di BEI periode 2008-2013). Jurnal Ekonomi Dan Bisnis, 10, 71-87.

Putranto, A. T. (2018). Analisis laporan keuangan untuk menilai kinerja keuangan pt mayora indah tbk tangerang. Jurnal SEKURITAS (Saham, Ekonomi, Keuangan Dan Investasi), 1(3), 1-26. https://doi.org/10.32493/skt.v1i3.1088

Putri, R. H. (2020). Pengaruh kebijakan perusahaan dan nilai perusahaan terhadap income smoothing. Jurnal Ilmu Dan Riset Akuntansi (JIRA), 9(4), 1-16.

Putri, S. D. A. (2015). Motif kecurangan, adanya kesempatan dan manipulasi laba. Jurnal Akuntansi Indonesia, 4(2), 123-130. DOI: http://dx.doi.org/10.30659/jai.4.2.133-141

Rahmah, M., \& Komariah, E. (2016). Analisis laporan keuangan dalam menilai kinerja keuangan industri semen yang terdaftar di BEI (studi kasus PT Indocement Tunggal Prakarsa tbk). Jurnal Online Insan Akuntan, 1(1), 43-58.

Rahmawantari, D. M. (2016). Pengaruh profitabilitas, risiko keuangan dan Price Earning Ratio (PER) terhadap perataan laba (Income Smoothing) pada industri perkebunan yang listing di Bursa Efek Indonesia. Jurnal Manajemen Bisnis Krisnadwipayana, 4(1), 1-8 https://doi.org/10.35137/jmbk.v4i1.24

Sekaran, U. (2011). Metodologi Penelitian untuk Bisnis (4th ed.). Salemba Empat.

Song, M., Oshiro, N., \& Shuto, A. (2016). Predicting accounting fraud: Evidence from Japan. The Japanese Accounting Review, 6(2016), 17-63. https://doi.org/10.11640/tjar.6.2016.01

Tabassum, N., Kaleem, A., \& Nazir, M. S. (2013). Impact of real earnings management on subsequent financial performance. Middle East Journal of Scientific Research, 17(4), 551-560. https://doi.org/10.5829/idosi.mejsr.2013.17.04.11986

Tangestani, E., Asgari, V., \& Jahed, I. (2016). The investigation of limiting factors of earnings management for companies listed Tehran stock exchange. Journal of Fundamental and Applied Sciences, 8(2), 1559-1571. https://doi.org/10.4314/jfas.v8i2s.93

Warsadi, K. A., Herawati, N. T., \& Julianto, P. (2017). Penerapan penyusunan laporan 
keuangan pada usaha kecil menengah berbasis standar akuntansi keuangan entitas mikro, kecil, dan menengah pada PT. mama jaya. E-Journal S1 Ak Universitas Pendidikan Ganesha, 8(2), 1-11. DOI: http://dx.doi.org/10.23887/jimat.v8i2.13773

Wells, J. T. (2011). Corporate fraud handbook: prevention and detection. John Wiley \& Sons.

Yulfita, D. (2014). Pengaruh profitabilitas, kebijakan dividen, dan pertumbuhan perusahaan terhadap praktik perataan laba. Jurnal Akuntansi Universitas Negeri Padang 2(20), 11-25. 